December 2020

\title{
Book Review: A Matter of Facts: The Value of Evidence in an Information Age
}

Terry Schiavone

San Jose State University, terrymschiavone@yahoo.com

Follow this and additional works at: https://scholarworks.sjsu.edu/ischoolsrj

Part of the Archival Science Commons, Cataloging and Metadata Commons, Collection Development and Management Commons, Information Literacy Commons, Museum Studies Commons, Scholarly Communication Commons, and the Scholarly Publishing Commons

\section{Acknowledgements}

$\mathrm{N} / \mathrm{A}$

\section{Recommended Citation}

Schiavone, T. (2020). Book Review: A Matter of Facts: The Value of Evidence in an Information Age. School of Information Student Research Journal, 10(2). https://doi.org/10.31979/2575-2499.100205 Retrieved from https://scholarworks.sjsu.edu/ischoolsrj/vol10/iss2/5

This article is brought to you by the open access Journals at SJSU ScholarWorks. It has been accepted for inclusion in School of Information Student Research Journal by an authorized administrator of SJSU ScholarWorks. For more information, please contact scholarworks@sjsu.edu. 


\section{Book Review: A Matter of Facts: The Value of Evidence in an Information Age}

Acknowledgements

N/A

\section{About Author}

Terry Schiavone is a 2020 graduate of SJSU iSchool's MLIS program, a MA in American History from West Chester University of Pennsylvania, and a BA in History from Wilkes University. He currently works as a digital processing specialist in the digitization unit at Penn State University Libraries. 


\section{Millar, L. A. (2019). A matter of facts: The value of evidence in an information age. ALA- Neal Schuman.}

Laura A. Millar's A Matter of Facts poignantly stresses the need for substantiated evidence to support facts. The book poses the question, how do we, the recordkeepers, hold institutions, governments, and individuals accountable for their actions? Her mantra throughout the book can be reflected in one statement, "We don't need facts alone. We need evidence" (2019, p. 20). As Millar suggests, society cannot respect the rule of law if we do not first demand trustworthiness from institutions and individuals that disseminate information. Millar in this work as well as her previous works like Archives: Principles and Practices stress that truth and fact rely on the accurate, unbiased nature of pointing to unfettered evidence (2017). Archives touches more intently on this theme - evidence and archives' role in upholding the integrity of records. Through her 35 years of experience as a records and archives consultant, Millar has also published other works related to archives including the 1988 work, A Manual for Small Rural Archives and the 2009 work, The story behind the book: Preserving Authors' and Publishers'. Evidence is foundational in our understanding of events and provides accountability for governments, organizations, and individuals. In a time where information manipulation readily corrupts and sways society in processing events, this work conveys expediency in safeguarding evidence from bad actors. Information professionals represent the front line in securing raw data, validating resources, and educating communities on distinguishing truths from lies. However, Millar believes the recordkeeper, the information professional, represents only one component, which requires a community effort to find solutions to protect evidence, particularly in the Digital Age.

A Matter of Facts addresses the precarious nature of evidence, particularly born-digital data, in the contemporary geopolitical landscape of the United States and beyond. It is comprised of ten chapters that espouse the importance of evidence, why evidence serves a critical role in authenticating information, and the dangers evidence poses when manipulated to serve nefarious agendas. In a post-truth society, access to evidence ensures the validity of facts. Millar posits that physical records, which remain static in form and distribution-and therefore unaltered or manipulated - are perceived more trustworthy than digital records. Though these records can be readily destroyed or rendered inaccessible to wide audiences or subjected to unreliable authors that employ censorship or omissions to protect themselves, Millar's greater concern focuses on digital content. Millar argues born-digital evidence plays a role in the accountability of others remains at risk of compromise not only from individuals, but also the processes of capturing and storing evidence. A Matter of Facts highlights the Information Age's immeasurable importance on the exchange of ideas, news, and society; and the book serves as a cautionary statement regarding the security and access to evidence.

The first half of the book focuses on evidence, how it is derived, and how evidence shapes identity and memory. Technology advances our connectedness and the content available to Web users; however, the validity of that content is always in question. Millar prefaced early in the work stated, "we live in an age when too many people prefer feelings over facts" $(2019$, p. 20). Too often information shared by users on social media platforms adhere to emotion rather than vetting the veracity of the source, which often warp our sense of the truth. Millar determines that political pundits as well as the American president frequently manipulate truths, which propound their political agenda. Beyond the accountability of bureaucrats and politicians, Millar directs readers to the importance of evidence for identity. In Chapter 5, she writes on the burgeoning ancestry databases and DNA test kits that help evidence heritage and authenticate our family histories and 
origins. Millar briefly mentions the African Diaspora, immigration, and $20^{\text {th }}$ and $21^{\text {st }}$ century refugee crises as clear examples when the channels to evidence have been interrupted or destroyed, resulting in a destructive effect imparted on one's identity. Millar uses ancestry in this section to evidence that not everyone can easily discover their heritage and that displaced peoples are disproportionately affected to access records that support identity.

The second half of the book directs the reader's attention to the fragility and vulnerability of digital information through intentional attacks on source integrity or manipulation of evidence. She highlighted examples such as Andrew Wakefield's infamous Lancet article on the MMR vaccine as the cause of autism, leading misguided readers of the statistics supporting these conclusions. Furthermore, Millar writes on privacy concerns, particularly whistleblowers that can be viewed, by some, as information liberators. However, Millar cautions that data leakage can be taken out of context and misconstrue audiences' interpretations of that data. Also, hackers can seize data or hold it hostage such as the WannaCry ransomware that attacked over 230,000 computers worldwide (2019, p. 104). In Chapter 9, she directs readers to society's perceived assumptions of the security and collection of evidence as well as the technology used to preserve these materials. In the concluding chapter, Millar suggests addressing recordkeeping guidelines for politicians, changing the law to support those guidelines, and a community effort to ensure accountability.

Overall, A Matter of Facts' relevancy in the Post-Truth era alerts readers to the precarious nature of digital information. The work reaffirms information professionals' responsibility in this respect-securing and providing information to those who seek it. However, Millar directs this cause not only for the recordkeeper but society. Throughout the book, Millar delivers insightful dialogue on recordkeeping with carefully crafted supporting evidence. Millar's well-written discourse, ample citations, and appendix list of resources provide readers with a firm foundation for further reading. Although it should be noted that for how rich and powerful Millar's words emanate, this remains an introduction to the topic of evidence-based truth. A Matter of Facts' scope covers a large area in less than 200 pages; therefore, readers need to rely on the further reading and citations to find more detailed information. With no sense of irony, another comparable work with a similar name, The Matter of Facts: Skepticism, Persuasion, and Evidence in Science promotes comparable information as Millar; however, the authors, Gareth and Rhodri Leng take a deeper dive into the methodology for scientific research and experimental evidence. Therefore, both works factor the relationship of evidence to authenticity. However, as Millar's work offers an overview of evidence throughout society, the Lengs' study directs readers on the importance of evidence in the scientific community. Further, the concise readability injunction with Millar's riveting writing style make for a quick and engaging read. Finally, A Matter of Facts is an excellent book not only for information professionals, but anyone with a passion and interest for recordkeeping.

\section{References}

Baird, D. A., \& Millar, L. A. (1988). A manual for small archives. Archives Association of British Columbia.

Leng, G., \& Leng, R. I. (2020). The matter of facts: Skepticism, persuasion, and evidence in science. MIT Press.

Millar, L. A. (2009). The story behind the book: Preserving authors' and publishers'. CCSP Press. 
Millar, L. A. (2017). Archives: Principles and practices. ALA-Neal Schuman.

Millar, L. A. (2019). A matter of facts: The value of evidence in an information age. ALA-Neal Schuman. 